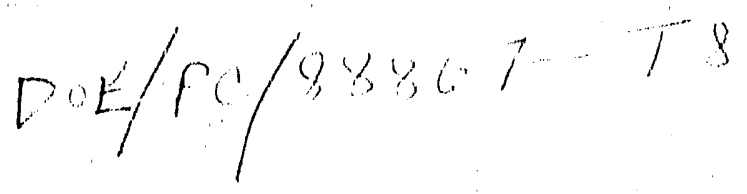

$\mathrm{DOE} / \mathrm{PC} / 88867--\mathrm{T} 8$

DE9 1000697

\title{
ELECTROSTATIC PRECIPITATION OF CONDENSED ACID MIST
}

\section{SIXTH QUARTERLY TECHNICAL PROGRESS REPORT}

April 1 to June 30, 1990

\author{
R. S. Dahlin, Project Manager \\ SOUTHERN RESEARCH INSTITUTE \\ 2000 Ninth Avenue, South \\ Birmingham, AL 35205
}

\author{
Thomas D. Brown, DOE Project Manager \\ Pittsburgh Energy Technology Center \\ Post Office Box 10940 \\ Pittsburgh, PA 15236
}

Prepared for the

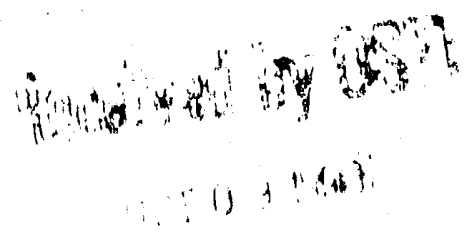

U.S. DEPARTMENT OF ENERGY

Under Contract No. DE-AC22-88PC88867

\section{SRI-ENV-90-683-6657-XXV}

\section{DISCLAIMER}

\footnotetext{
This report was prepared as an account of work sponsored by an agency of the United States Government. Neither the United Stat:s Suvernment nor any agency thereof, nor any of their employees, makes any warranty, express "r implied, or assumes any legal liability or responsibility for the accuracy, completeness, or usefulness of any information, apparatus, product, or process disclosed, or represents that its use would not infringe privately owned rights. Reference herein to any specific commercial product, process, or service by trade name, trademark, manufacturer, or otherwise does not necessarily constitute or imply its endorsement, recommendation, or favoring by the United States Government or any agency thereof. The views and opinions of authors expressed herein do not necessarily state or reflect those of the United States (jovernment or any agency thereof.
}

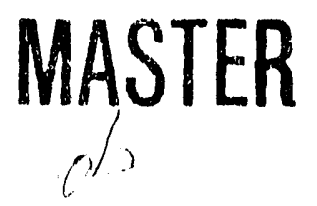




\section{TABLE OF CONTENTS}

\section{ELECTROSTATIC PRECIPITATION OF CONDENSED ACID MIST}

Sixth Quarterly Technical Progress Report

Page

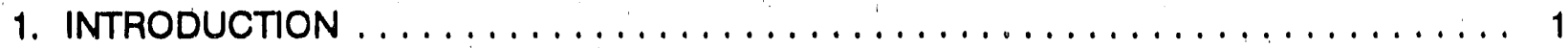

1.1. Technical Background $\ldots \ldots \ldots \ldots \ldots \ldots \ldots \ldots \ldots \ldots \ldots \ldots \ldots$

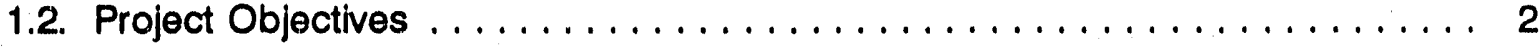

1.3. Project Structure and Scope $\ldots \ldots \ldots \ldots \ldots \ldots \ldots \ldots \ldots \ldots \ldots$

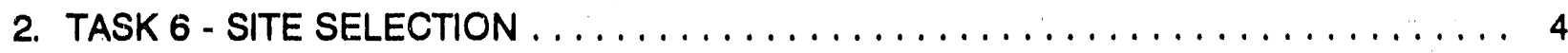

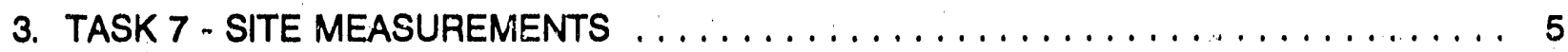

4. TASK 8 - COMPUTER MODELING AND DEMONSTRATION PLAN $\ldots \ldots \ldots \ldots \ldots 7$

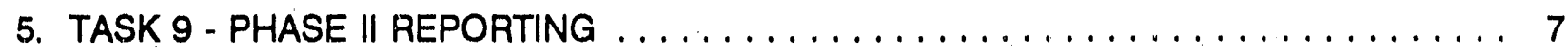

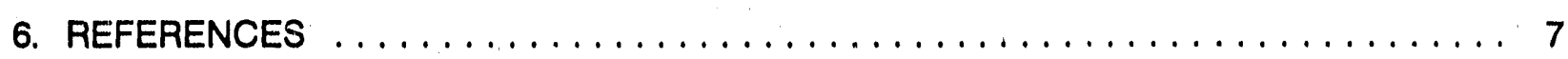




\section{INTRODUCTION}

\subsection{Technical Background.}

This project addresses the acid mist that is formed by condensation of sulfuric acid vapor in flue gas from coal-fired utility boilers. An acid mist can be formed whenever the flue gas temperature approaches the prevailing acid dew point. This commonly occurs when the gas is subjected to rapid adiabatic cooling in a wet scrubber system for flue gas desulfurization. Acid mists can also sometimes result from unexpected temperature excursions caused by air inleakage, load cycling, and start-up operations.

Most of the acid mist that is formed in a wet scrubber system escapes collection in the scrubber (1). This is a result of the extremely fine droplet size in the acid mist, which allows the mist droplets to follow the gas streamlines around the droplets of scrubber slurry, thereby avoiding collection by inertial impaction or interception.

Acid mists can sometimes constitute a significant portion of the total particulate emissions from power plants burning high-sulfur coals. Complete condensation of $10 \mathrm{ppm}$ of acid vapor produces a condensed acid mass loading of about $0.02 \mathrm{gr} / \mathrm{dscf}$ or $0.03 \mathrm{lb} / \mathrm{MMBtu}$, equivalent to the total allowable mass emissions under the revised (1979) New Source Performance Standards (2). 
In some states, the mass emission sampling protocols allow exclusion of the acid mass from the total particulate sample (cf 3). Even in these cases, the acid mist can be a limiting factor due to its effect on opacity. The acid mist droplets are predominantly in the size range of 0.1 to $1 \mu \mathrm{m}$ (4), where light scattering is very efficient. In some cases, the droplet size distribution seems to be concentrated in the 0.4 to $0.5 \mu \mathrm{m}$ range, near the wavelength of blue light, giving the plume a bluish tint (5). Due to these considerations, it may be necessary to reduce acid mist emissions even when their contribution to the total particulate mass is relatively small.

A wet electrostatic precipitator (WESP) is the best control option for acid mist. The mist would blind a fabric filter and attack glass fiber fabrics. A wet ESP is required because the acid would quickly corrode the plates in a converitional dry ESP. The wet ESP also offers the advantages of no rapping reentrainment and no sensitivity to fly ash resistivity. Therefore, this program has been structured around the use of a compact, wet ESP to control acid mist emissions.

\subsection{Project Objectives}

The purpose of this project is to develop and demonstrate a compact, wet electrostatic collector for condensed acid mist in power plant flue gas. In order to accomplish this goal, several objectives must be met.

1. A laboratory-version of the WESP must be fabricated.

2. The WESP performance must be optimized through laboratory tests with a non-volatile simulant aerosol having a size distribution similar to the acid mist. 
3. The WESP concept must be proven by demonstrating adequate collection of actual acid mist in a pllot coal combustion facility under coriditions simulating a full-scale power plant burning high-sulfur coal.

4. A computer model of the WESP process must be developed to assist in the process optimization, interpretation of test results, and extrapolation to full scale.

5. Field measurements of the mass loading and size distribution of acid mist, fly ash, and scrubber solids must be made to provide a reliable basis for projecting WESP performance.

6. Computer projections of WESP performance and size requirements must be made to serve as a basis for the design of a prototype WESP.

7. Utility participation must be solic led in a follow-on demonstration of the WJESP prototype at a full-scale power plant.

Objectives 1-4 were satisfied under Phase I of the contract. Objectives 5-7 apply to the current effort under Phase II.

\subsection{Project Structure and Scope}

The project is organized in two phases. Phase I, which was initiated in September 1988 and completed in November 1989, involved the WESP fabrication, laboratory and pilot combustor testing, and computer modeling. Phase II, which is scheduled for January 1990 to January 1991, 
involves the solicitation of a utility demonstration site, preliminary site measurements, and planning for the demonstration test program. All of the Phase I work was summarized in the Phase I Final Report (6), which was reviewed and approved by DOE. Only Phase II work will be addressed in this discussion.

Phase II is organized in four tasks as follows:

Task 6. Site Selection

Task 7. Site Measurements

Task 8. Computer Modeling and Demonstration Plan

Task 9. Phase II Reporting

\section{TASK 6 - SITE SELECTION}

As discussed in the last quarterly report, TVA's Paradise Station has been selected as the site for the first field test. The test is scrieduled for July 16 to 24 . Detalls of the test plan are given in Section 3 of this report.

For the second field test, there are two candidate sites: TVA's Vi,Jows Creek Station and NSP's Sherce Station. The Widows Creek site offers the potential for another test with a significant loading of acid mist. The Sherco site offers the potential for a test with no acid mist, but a 
significant loading of fly ash. The possibility of cost sharing by TVA and NSP is being investigated to determine if the project could be expanded to include both of these sites (i.e., a total of three sites, instead of two). This expansion of the project may also require a time extension from DOE.

The characteristics of both the Widows Creek and the Sherco sites were taken from the PEDCo FGD Survey (7) and reported in the last quarterly report. Site visits are recommended to verify this information and discuss the proposed testing with plant personnel.

\section{TASK 7 - SITE MEASUREMENTS}

As mentioned above, the site measurements at the Paradise Plant are currently scheduled for July 16 to 24. The measurements will include U. W. Mark V impactors (heated to avoid condensation on the walls) and controlled condensation technique for $\mathrm{SO}_{3}$. The impactor measurements will be made upstream and downstream of the mist eliminators at the locations shown in Figure 1. The $\mathrm{SO}_{3}$ measurements will be made in the common duct at the inlet of the FGD system.

The test plan for the Paradise site is given below.

\begin{tabular}{|c|c|c|}
\hline Sunday & $7 / 15$ & Travel \\
\hline Monday & $7 / 16$ & Set Up Equipment \\
\hline Tuesday & $7 / 17$ & Impactors at M.E. Outlet $--\mathrm{SO}_{3}$ at ESP Outlet \\
\hline Wednesday & $7 / 18$ & Sarne as Above \\
\hline Thursday & $7 / 19$ & Same as Above \\
\hline Friday & $7 / 20$ & Impactor's at M.E. Inlet \\
\hline Saturday & $7 / 21$ & Same as Above \\
\hline Sunday & $7 / 22$ & Same as Above \\
\hline Monday & $7 / 23$ & Take Down Equipment \\
\hline Tuesday & $7 / 24$ & Travel \\
\hline
\end{tabular}




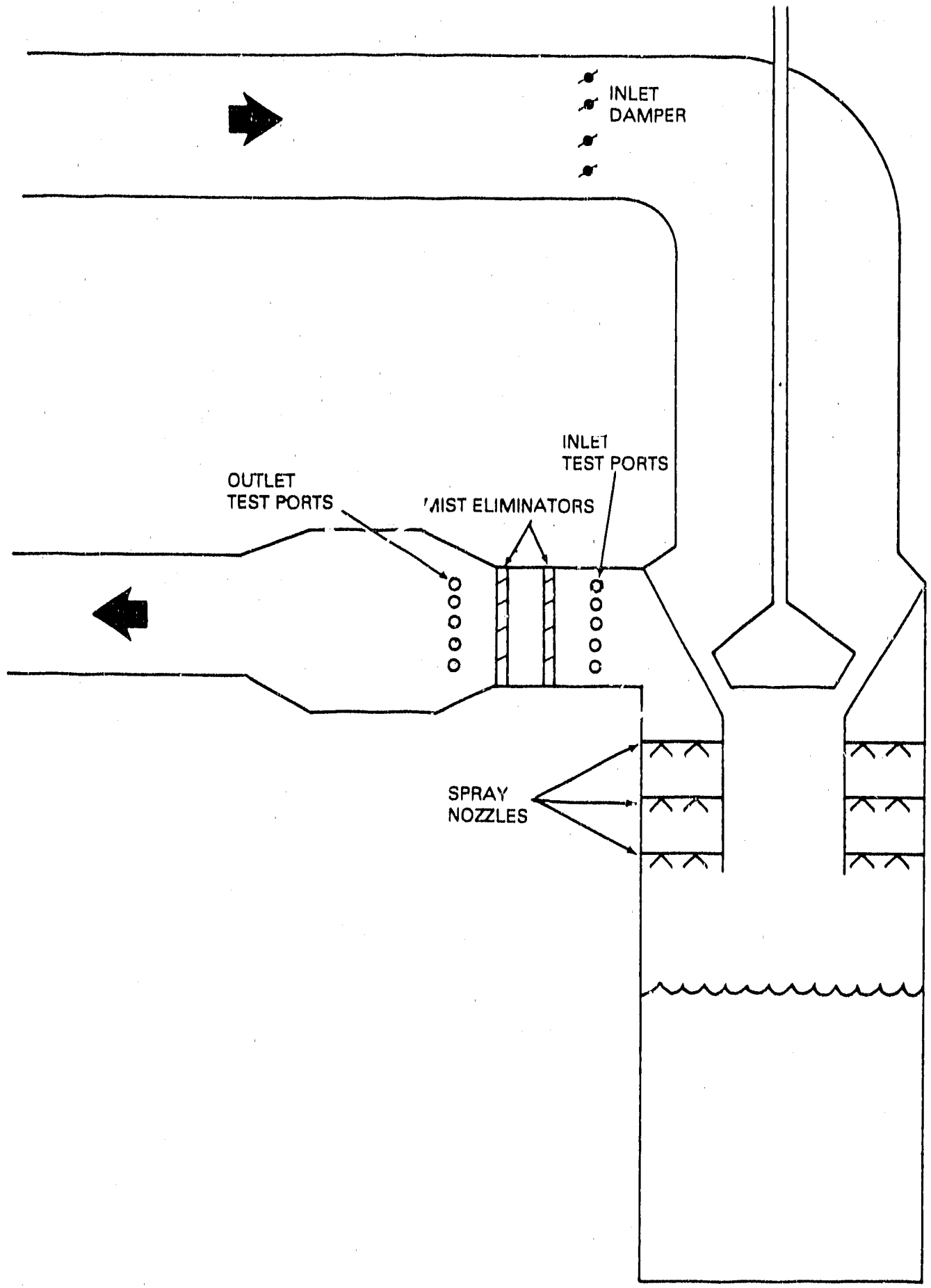

Figure 1. Sketch of Paradise Scrubbier Module showing locations of inlet and outlet test ports. 
If arrangements can be made with TVA and if time permits, tests may also be done with one of the mist elliminators removed. This would simulate the condition recommended by Flakt for installation of a WESP.

\section{TASK 8 - COMPUTER MODELING AND DEMONSTRATION PLAN}

Work on this task will begin after the field results are available. The results will be analyzed and used in the WESP computer model to project WESP performance in this application. A plan for demonstrating a prototype WESP will then be developed.

5. TASK 9 - PHASE II REPORTING

All monthly status and cost management reports have been subınitted on schedule. The project is on schedule at this point in time.

6. REFERENCES

1. Laslo, D., E. Bakke, and E. Chisholm, "Limestone/Adipic Acid FGD and Stack Opacity Reduction Pilot Plant Tests at Big Rivers Electric Corporation", Peabody Process Systems Incorporated, Technical Report, 1984.

2. New Source Performance Standards: Electric Utility Steam Generating Units. Federal Register 44 (113):33580-33624 (June 11, 1979). 
3. Wesa, A. W., "Study of Various Sampling Procedures for Determining Particulate Emissions from Coal-Fired Steam Generators", Combustion, July 1977, pp. 34-39.

4. Krall, M. J., M. R. Fuche, and W. D. Baffour, "Characterization of Flue Gas Emissions from the PPSI FGD Pilot Plant", Technical Report - Vol. I, Radian Corporation, February 1983.

5. Jaasund, S. A., "E-Tube Wet Electrostatic Precipitator - Leading Plywood Test Results", Geoenergy International Corporation, Report to Leading Plywood Corporation, 1988.

6. Dahlin, R. S., "Electrostatic Precipitation of Condensed Acid Mist", Phase I Final Report submitted by Southern Research Institute to DOE/PETC under Contract No. DE-AC2288PC88867, November 1989.

7. Melia, M. T., R. S. McKibben, and B. W. Pelsor, "Utility FGD Survey", EPFI Report CS-3369, submitted by PEDCo Environmental, Inc., under EPRI Contract No. RP982-32, Electric Power Research Institute, Palo Alto, CA, October 1984 

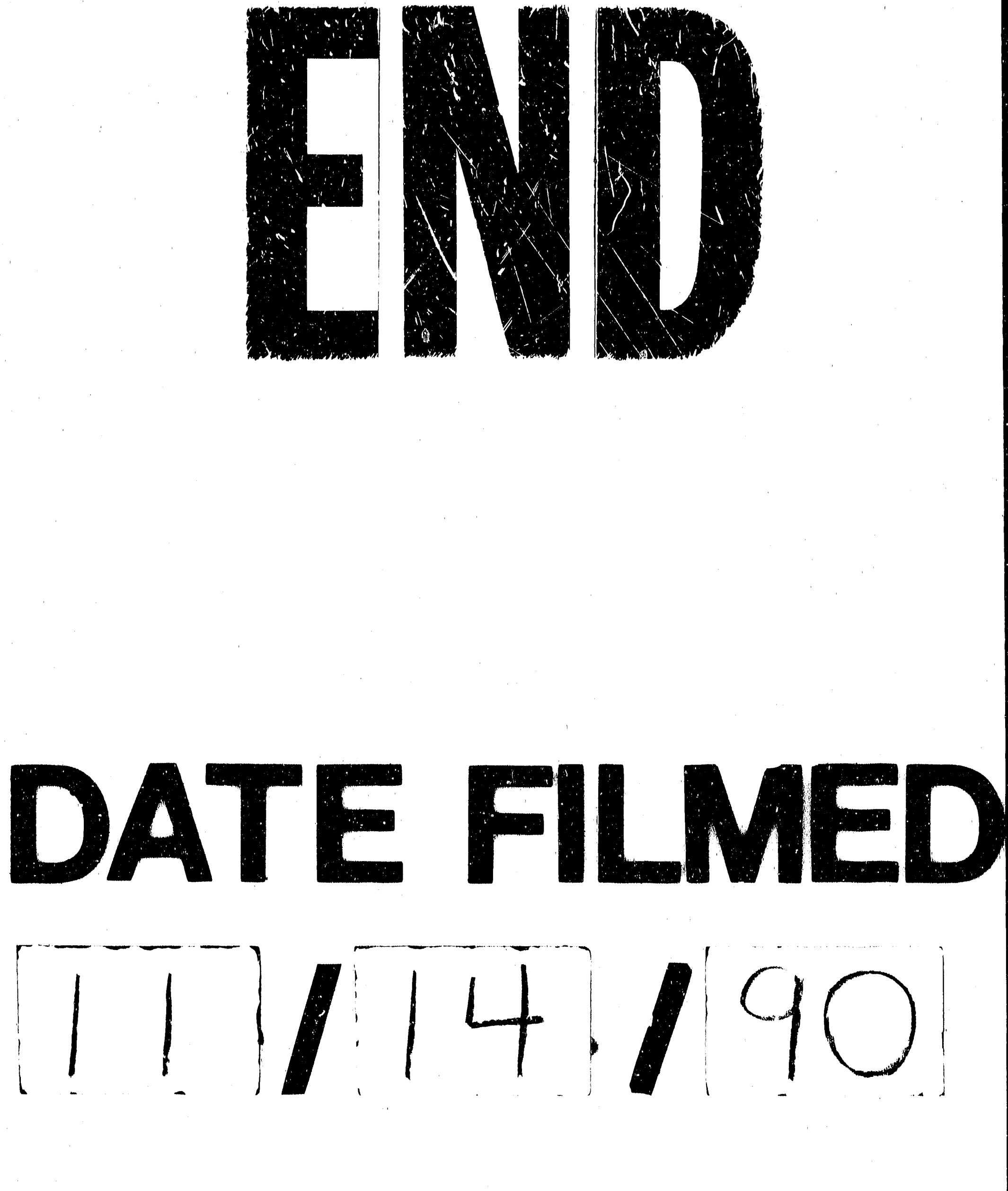
